\title{
Genes, folate and homocysteine in embryonic development
}

\author{
Thomas H. Rosenquist ${ }^{1 *}$ and Richard H. Finnell ${ }^{1,2}$ \\ ${ }^{1}$ Department of Cell Biology and Anatomy \\ ${ }^{2}$ Center for Human Molecular Genetics, University of Nebraska Medical Center, Omaha, NE 68198-6395, USA
}

\begin{abstract}
Population-based studies of human pregnancies show that periconceptional folate supplementation has a significant protective effect for embryos during early development, resulting in a significant reduction in developmental defects of the face, the neural tube, and the cono-truncal region of the heart. These results have been supported by experiments with animal models. An obvious quality held in common by these three anatomical regions is that the normal development of each region depends on a set of multi-potent cells that originate in the mid-dorsal region of the neural epithelium. However, the reason for the sensitive dependence of these particular cells on folic acid for normal development has not been obvious, and there is no consensus about the biological basis of the dramatic rescue with periconceptional folate supplementation. There are two principal hypotheses for the impact of folate insufficiency on development; each of these hypotheses has a micronutrient component and a genetic component. In the first hypothesis the effect of low folate is direct, limiting the availability of folic acid to cells within the embryo itself; thus compromising normal function and limiting proliferation. The second hypothetical effect is indirect: low folate disrupts methionine metabolism; homocysteine increases in the maternal serum; homocysteine induces abnormal development by inhibiting the function of N-methyl-D-aspartate (NMDA) receptors in the neural epithelium. There are three general families of genes whose level of expression may need to be considered in the context of these two related hypotheses: folate-receptor genes; genes that regulate methioninehomocysteine metabolism; NMDA-receptor genes.
\end{abstract}

Genes: Folate: Homocysteine: Embryonic developmental defects

A significant decrease in cono-truncal, facial-clefting and neural-tube defects can be achieved with the simple and inexpensive step of taking supplemental periconceptional folic acid (Czeizel \& Rhode, 1984; Seller \& Nevin, 1984; Steegers-Theunissen et al. 1994; Shaw et al. 1995; Botto et al. 1996; Czeizel et al. 1996; Wald et al. 1996). Numerous other experimental teratogens and maternal exposures have also been associated, in a highly specific way, with these three anatomical regions, as we have discussed previously (Andaloro et al. 1998; Rosenquist et al. 1999).

The biological basis for the similar sensitivities to disrupted development that are shown by these widelyseparated anatomical sites is their common dependence on cells that originate in the neural epithelium. Cells of the cephalic neural crest contribute significantly to development of the face (Noden, 1975, 1978a,b, 1983), as well as to the cono-truncal region of the heart (Kirby et al. 1983; Kirby \&
Waldo, 1990, 1995). Furthermore, premigratory neural-crest cells are virtually indistinguishable from the dorsal-most presumptive neurons of the neural fold, both anatomically and functionally (Scherson et al. 1993); it is these cells that participate in neural-tube closure. Thus, it is reasonable to predict that if supplementary folate has a positive effect on the development of one of these regions, it will have a similar effect on the others; the positive result obtained in the population-based studies cited earlier is therefore predictable as well.

However, the positive effect of the supplementary folate appeared to be highly specific for neural-crest and neuraltube cells, indicating the possibility that these particular cells were more sensitively dependent on the presence of a high folate concentration than other embryonic cells; the basis of this dependence was not necessarily intuitive. Nevertheless, its meaning was obviously a reflection of some previously unsuspected aspect of the biology of the 
neural-crest and neural-tube cells. We have considered a number of possibilities for this effect, and we have derived two related hypotheses: the 'direct effect' hypothesis; the 'indirect effect' hypothesis.

\section{The 'direct effect' hypothesis}

\section{Background}

The most simple, and most obvious, explanation for the positive effect of folate supplementation is that maternal folate deficiency is more common than had been expected, and that supplementation remedies this deficit, resulting in a significant positive effect on development. However, the protective effect of periconceptional folic acid supplementation for neural-tube defects was not found to be dependent on a pre-existing overt folate deficiency in the mother (Yates et al. 1987). Given the lack of evidence for a maternal folate deficiency, the embryo rescue afforded by maternal vitamin supplementation may be the result of a direct positive effect on the cells of the embryo itself (Finnell et al. 1998). Thus, we derived a 'direct effect' hypothesis to explain the protective role of supplementary folate.

One of the key bases of this hypothesis is that cells of the neural epithelium, precursor of both the neural crest and the neural tube, express very high levels of the message for folate receptors (Finnell et al. 1997; Piedrahita et al. 1999). Although most embryonic cells lack these receptors, cells with specific metabolic requirements for high levels of folate need to express these receptors to sequester and transport folate into the cell. Thus, we have considered that the neural epithelium may be uniquely susceptible to folate insufficiency, because of a previously unsuspected high order of folate utilization in those cells. In this case, the key to normal development would lie with the ability of the embryo itself to utilize folate. It may be hypothesized that these highly vulnerable regions of the embryo might be so exquisitely sensitive to ambient folate that even a small decline in maternal folate concentration could be sufficient to change the direction of development, and a deficiency in the transport or metabolism of folic acid in the embryo itself would be a key perturbation, rather than a frank maternal folate insufficiency. In this case developmental abnormalities of the neural crest and neural tube would occur at a uniquely high rate when maternal folic acid was reduced even slightly.

It is likely that complex nutrient-gene interactions regulate the sensitivity of developing embryos to the induction of, or protection from, developmental abnormalities that originate in the neural epithelium. Recent advances in gene technology and knowledge of the murine genome have resulted in increasing utilization of the transgenic mouse embryo model to test hypotheses relating to early embryonic events. In keeping with the fruitful application of transgenic mouse technology to address the role of folate in the development of the neural epithelium, our laboratories recently reported the development of 'knockout' mouse model systems to test critical hypotheses involving the regulation of intracellular folate, as they relate to neuralcrest and neural-tube development. For the initial transgenic mouse experiments we selected the murine folate-bindingprotein gene (Folbp1; homologue of human FR $\alpha$ ). The Folbpl 'knockout' mouse was described by us recently (Piedrahita et al. 1999).

Folbpl is narrowly distributed among intra-embryonic tissues, in those areas of high folate requirement; for example, in the early embryo Folbpl is found almost exclusively in the neural epithelium (neural crest and neural tube). Thus, intracellular folate availability in these key areas of Folbpl -/- embryos becomes a stoichiometric function of the extracellular folate concentration, and uniquely permits highly-sensitive regulation of intracellular folate. Teratogenesis and mortality are both inversely related to folate availability, as regulated stoichiometrically in this model (Table 1).

With this unique model, we tested the hypothesis that abnormal development of derivatives of the neural epithelium would result from a direct effect of folate insufficiency on embryonic cells. According to this hypothesis a deficiency in transport and/or metabolism of folate puts embryos at risk for abnormal development, and maternal folic acid supplementation helps overcome this deficiency. According to the hypothesis these defects are a direct result of folate insufficiency on the growth and differentiation of embryonic cells, especially those derived from the neural epithelium. Genes in the folate transport pathway were selected for the initial tests of this hypothesis.

\section{Experiments with the transgenic mouse model}

Abnormal phenotype of Folbp1-deficient embryos. The Folbpl -/-gestational day 8, 12 h embryos showed a global reduction in growth, with specific sites of dysmorphogenesis; e.g. gross abnormalities of the neural tube included absence of the forebrain and the optic vesicles. The branchial arches and the hearts of Folbpl -/- embryos were obviously smaller than normal (Piedrahita et al. 1999). To quantify these differences, for the present report we carried out a morphometric analysis of the branchial arches and hearts in Folbpl -/- gestational day 8, $12 \mathrm{~h}$ embryos, according to our published methods (for example, see Rosenquist et al. 1990c). The results showed that the number of ectomesenchymal cells in a given branchial arch of a nullizygous embryo was on average $<15 \%$ of the normal value $(P<0.001)$. This deficit is inconsistent with normal branchial arch and cono-truncal development, as has been shown by numerous analyses of the cardiac neural crest (for example, see Bockman et al. 1990).

Although the heart tube was smaller in all nullizygous embryos as reported previously (Piedrahita et al. 1999), this reduction was in proportion to the smaller size of the whole embryo. The morphometric analysis reported here showed that the thickness of the area between the myocardium and the endocardium containing the cell-free extracellular matrix, historically referred to as the 'cardiac jelly', was reduced disproportionately, so that the extracellular matrix in nullizygous embryos comprised only $25 \%$ of the whole wall thickness $v .45 \%$ in normal embryos $(P<0 \cdot 001)$. This result may indicate impairment of the ability of the myocardium to synthesize and maintain the extracellular matrix in the nullizygous embryos. 
Typically, these nullizygous embryos die early, presumably from morphological defects secondary to a global folate deficiency. By appropriate timing of the stoichiometric manipulation of folate these embryos can be rescued from death. However, numerous studies have shown that the effect of early perturbation of the neural crest and neural tube is not reversible. Thus, developmental processes can be perturbed at different times, and to different degrees, by careful regulation of folate concentration in this unique model.

\section{Dose-response effect of phenotypic rescue}

Crosses between mice heterozygous for the Folbpl gene deletion produced small litters, with no Folbp1 -/survivors, indicating an embryonic lethal mutation. Although Folbp1 facilitates passage of folate into cells, passive transfer also occurs. Thus, if the only relevant effect of the Folbpl -/- or +/- genotype is to regulate intracellular folate concentration, increased embryonic extracellular folate concentration via high doses of maternally-administered folate should rescue the normal phenotype. In the absence of supplemental folic acid, $100 \%$ of the Folbpl -/- embryos developed abnormally (see earlier discussion), but when Folbpl +/- dams were bred to sires heterozygous for the null allele, and were orally intubated with $25 \mathrm{mg}$ folic acid/ $\mathrm{kg}$ before conception and throughout gestation, supplemental folic acid effectively rescued the normal phenotype in twelve of thirteen embryos lacking a functional Folbpl gene $(P<0.05)$. These results have been reported previously (Piedrahita et al. 1999). Here, we report the dose-response effect of folinic acid supplementation.

Folbp1 +/- dams bred to Folbp1 +/- sires were supplemented by oral intubation with $6 \cdot 125,12 \cdot 5$, or $25 \mathrm{mg}$ folinic acid (the physiologically-active form of folic acid) $/ \mathrm{kg}$. Supplementation of heterozygous Folbpl dams with high doses of folinic acid $(25 \mathrm{mg} / \mathrm{kg})$ before and throughout gestation successfully rescued the phenotype in $66 \%$ of the nullizygous embryos (Table 1). Low dose $(6 \cdot 125 \mathrm{mg} / \mathrm{kg})$ and intermediate dose $(12.5 \mathrm{mg} / \mathrm{kg})$ supplementation with folinic acid prolonged in utero survival of nullizygous embryos (gestational day 18, 0h), but they consistently presented with defects of the neural tube, face and conotruncus.

\section{Conclusion}

The data presented here clearly demonstrate that the Folbp 1 nullizygous embryos had severe developmental abnormal- ities of neural-crest and neural-tube derivatives, and these abnormalities are characteristic of the general set of related abnormalities on which these hypotheses are based. It is important for future use of this model that the abnormal phenotype can be rescued with high doses of supplemental folic acid as well as folinic acid, demonstrating that it is possible to rescue embryos by dietary supplementation, even in the absence of a functional folate-receptor mechanism. These results support the general hypothesis that highly-vulnerable regions of the embryo, especially the neural epithelium, are highly sensitive to ambient folate concentration, and a deficiency in the transport or metabolism of folic acid in the embryo itself appears to be sufficient to induce abnormal development of derivatives of the neural epithelium. Furthermore, these data indicate one mechanism whereby supplementary folate could have a positive effect on development, even in the absence of a frank deficit in maternal folate concentration. Another mechanism that may provide the same possibility is now described.

\section{The 'indirect effect' hypothesis}

\section{Background}

Our previous results, as well as other sources, have indicated that an elevated homocysteine concentration may induce abnormal development of neural-crest and neural-tube derivatives, even in the absence of a frank deficit of folic acid. Furthermore, homocysteine has been shown to inhibit the N-methyl-D-aspartate (NMDA) type of glutamate receptor under certain conditions, and NMDA-receptor antagonists are among the most common teratogens for the neural crest and neural tube. Indeed, the ability to perturb development of these areas appears to be a general property of compounds that inhibit the NMDA receptor (Andaloro et al. 1998). Thus, we hypothesize that homocysteine may induce cono-truncal defects, and associated defects of the neural crest and neural tube, by its ability to inhibit the activity of NMDA receptor. These are two major corollaries to this hypothesis. First, NMDA-receptor agonists will restore normal development during episodes of elevated homocysteine. Second, and conversely, homocysteine may interact with other compounds that also inhibit the NMDA receptor, and this interaction in some cases will exacerbate the disruption of normal development. As a result, homocysteine may have a central role in determining the ultimate impact of clinically-important human teratogens.

Table 1. Effect of supplementation with folinic acid (the physiologically-active form of folic acid) by oral intubation of Folbp $+/-$ dams bred to Folbp +/- sires, before and throughout gestation at $6.125,12.5$ or $25.0 \mathrm{mg} / \mathrm{kg}$

\begin{tabular}{|c|c|c|c|c|c|c|c|c|c|c|}
\hline \multirow{3}{*}{$\begin{array}{l}\text { Folinic acid } \\
\text { treatment }(\mathrm{mg} / \mathrm{kg})\end{array}$} & \multirow{3}{*}{$\begin{array}{l}\text { No. of } \\
\text { litters }\end{array}$} & \multirow{2}{*}{\multicolumn{3}{|c|}{ No. of embryos }} & \multicolumn{6}{|c|}{ Embryo genotype } \\
\hline & & & & & \multicolumn{2}{|c|}{$+/+$} & \multicolumn{2}{|c|}{$+1-$} & \multicolumn{2}{|c|}{$-1-$} \\
\hline & & Total & Resorbed & Live & Normal & Abnormal & Normal & Abnormal & Normal & Abnormal \\
\hline $6 \cdot 125$ & 3 & 18 & 2 & 16 & 8 & 0 & 6 & 0 & 0 & 2 \\
\hline $12 \cdot 5$ & 5 & 43 & 0 & 43 & 14 & 0 & 25 & 0 & 0 & 4 \\
\hline $25 \cdot 0$ & 6 & 47 & 0 & 47 & 12 & 0 & 29 & 0 & 4 & 2 \\
\hline
\end{tabular}




\section{Experiments with the chicken-embryo model}

As discussed earlier, other researchers had suggested that folate supplementation might be protective in part because it inevitably resulted in lower maternal serum homocysteine (Steegers-Theunissen et al. 1994, 1995; Thomas et al. 1994; van der Put et al. 1995), and some population-based studies had shown that hyperhomocysteinaemia increased the risk for neural-tube and neural-crest defects (Eskes, 1998; Kapusta et al. 1999), even in the presence of normal levels of folate (Mills et al. 1999). Altered expression of genes for enzymes in the methionine metabolism pathway were especially important in cases of non-dietary hyperhomocysteinaemia, including cystathione $\beta$-synthase (CBS), methionine synthase (MS), and methyltetrahydrofolate reductase (MThFR). These genes are discussed further (pp. 58-59).

We adapted the 'homocysteine as a teratogen' hypothesis to animal experiments, and designed a test of the hypothesis that homocysteine could induce cono-truncal, oro-facial and neural-tube defects, using the chicken-embryo model. An extensive narrative about the various kinds of experiments that led to this hypothesis has been published recently (Rosenquist \& Monaghan, 2000). This background will be summarized, and more recent data that support the hypothesis will also be provided. The avian-embryo model has been used extensively to establish the role of the neural crest in oro-facial and cono-truncal development (for example, see Kirby et al. 1983, 1990; Noden, 1975, $1978 a, b, 1983)$, and we had used the avian model previously for neural-crest studies to analyse the developmental fate of neural-crest-derived ectomesenchyme (for example, see Rosenquist et al. 1988, 1990a,b,c, 1996, 1999; Theiszen \& Rosenquist, 1995; Theiszen et al. 1996). To test the hypothesis we treated avian embryos with various concentrations of exogenous homocysteine during the processes of gastrulation, neurulation and cono-truncal septation. The results showed that homocysteine induced oro-facial, cono-truncal and neural-tube defects in a dose- and timedependent fashion (Rosenquist et al. 1996, 1999). However, these experiments did not show the cellular or molecular mechanism(s) responsible for this effect.

Homocysteine has been shown to be cytotoxic in some studies in vitro; but cytotoxicity resulted principally when the concentration of homocysteine was fifty to 100 times normal, or five to ten times the highest concentration that was found to be teratogenic. Our experiments did not support a cytotoxic effect of homocysteine. There appeared to be abnormal aggregations of cells in the developmentallydisrupted regions of homocysteine-treated embryos, rather than a reduction in the number of cells. Duplication of notochords, spinal cord and spinal ganglia were common, rather than reduction or absence of these key structures (Rosenquist et al. 1996). The ectomesenchymal cells in the cardiac outflow tract were present and abundant, but ectopic (Rosenquist et al. 1996). Taken together, these results did not indicate that the abnormal embryos had been subjected to some event that killed cells of the cardiac neural crest, other areas of the neural crest, or the neural tube. The presence of abundant cells from the neural ectoderm, and the duplicated notochords, implied an increase in mitosis, a decrease in embryonic apoptosis (a critical feature of both neural-crest and neural-tube development; Graham et al. 1996; Graham \& Lumsden, 1996; Weil et al. 1997), or both. Considering the results of either increased mitosis or decreased apoptosis, or some combination of these processes, the most likely mode of action of homocysteine would be via some receptor-mediated event. Although no 'homocysteine receptor' had been described, Lipton et al. (1997) had found that homocysteine was capable of acting on the NMDA type of glutamate receptor, depending on the nature of the solution, as an agonist or as an antagonist. Although no other investigation had specifically identified teratogenicity as a general property of NMDA-receptor antagonists, the literature in fact held many examples of compounds whose pharmacological effects include inhibition of the NMDA receptor, and are also known to be associated with relevant developmental abnormalities. These compounds include, for example, ethanol (Bhave et al. 1996; Johnson et al. 1996; Munger et al. 1996), some anti-tussives (Ferencz et al. 1997; Andaloro et al. 1998) and valproic acid (Nau, 1985; Gofflot et al. 1996; Finnell et al. 1997). Although these compounds have effects other than NMDA-receptor antagonism, the NMDA receptor seems uniquely suited as a potential target for teratogens, since it regulates virtually all the intracellular and intercellular events that are central to neural-tube closure and neuralcrest migration (Cornell-Bell et al. 1990; Rashid \& Cambray-Deakin, 1992; Komuro \& Rakic, 1993; Wang et al. 1996; Uberti et al. 1998). The hypothesis derived from this information was that inhibition of the NMDA receptor by homocysteine may disrupt development of the neural crest and neural tube. We evaluated a set of NMDA-receptor antagonists that were selected to represent three different classes, each acting at a different site on the hetero-oligomeric NMDA receptor. The results indicated that the ability to induce abnormal neural-tube and neural-crest development was a general characteristic of antagonists of the NMDA receptor (Andaloro et al. 1998).

According to these results, developmental abnormalities should be reduced or prevented by activation of the NMDA receptor during episodes of hyperhomocysteinaemia. To test this hypothesis we treated embryos during the process of neural-tube closure with sufficient homocysteine to induce neural-crest and neural-tube defects in about $40 \%$ of survivors, along with NMDA-receptor agonists given simultaneously, to activate the receptor and, according to the hypothesis, to rescue the embryos. At their most effective doses the agonists D-cycloserine, glutamate and glycine each provided protection; however, glycine was the most effective overall, reducing defects by about half ( $P<0.001 ;$ Rosenquist et al. 1999). For the present report, we have carried out further experiments to optimize the timing of the receptor activation. When glycine was provided $30 \mathrm{~min}$ before the administration of homocysteine, embryo rescue improved to $70 \%$ (Fig. 1). When D-cycloserine was given 30 min before homocysteine, about $50 \%$ of the embryos were rescued (Fig. 1), whereas $37.5 \%$ of the embryos were rescued when homocysteine and D-cycloserine were given at the same time (Rosenquist et al. 1999). These results support the hypothesis that 


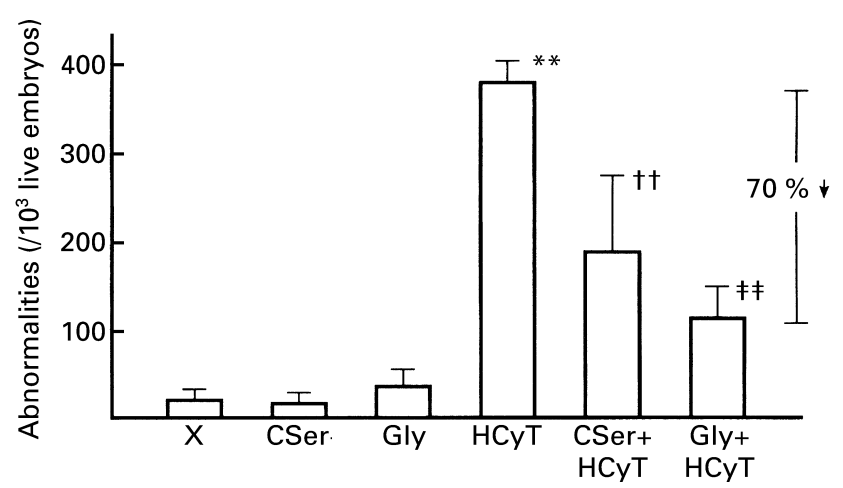

Fig. 1. Chicken embryos were treated during the process of neuraltube closure with the N-methyl-D-aspartate (NMDA) receptor glycinesite agonists D-cycloserine ( $50 \mathrm{nmol}$; CSer) or glycine $(50 \mathrm{nmol} ; \mathrm{G})$, or with sufficient homocysteine thiolactone ( $5 \mu \mathrm{mol}$; HCyT) to induce neural-crest and neural-tube defects in about $40 \%$ of survivors. Another set of embryos was given CSer or Gly, and after 30 min the same embryos were treated with HCyT. There were 280 embryos in each group. When it was given 30 min before HCyT, CSer was able to rescue about half the embryos that were expected to be abnormal, and Gly rescued about $70 \%$. X, vehicle control. Values are means with their standard errors represented by vertical bars. The means for abnormal embryos per group were compared using a single-factor ANOVA, followed by a Fisher post hoc analysis (Statview 2.0; Abacus Concepts Inc., Berkeley, CA, USA). Mean value for HCyT was significantly different from that for $\mathrm{X}:{ }^{\star \star} P<0.01$. Mean value for CSer + HCyT was significantly different from those for CSer and $\mathrm{HCyT}: \dagger \dagger P<0.01$. Mean value for Gly+HCyT was significantly different from that for HCyT: $\ddagger \ddagger P<0.01$.

homocysteine may affect neural-crest and neural-tube development by its ability to inhibit the NMDA receptor.

It may be predicted that homocysteine may interact with other NMDA-receptor antagonists to increase the rate of occurrence or severity of congenital defects of the neural crest and neural tube. For an initial test, we treated embryos with homocysteine in combination with ethanol, or the widely-used anti-tussive-anti-convulsant dextromethorphan. Ethanol is an ideal candidate since it is a potent $\gamma$-aminobutyric acid receptor agonist as well as an NMDA-receptor antagonist; also, one of its NMDA-binding sites (the phencyclidine-binding site; Hundt et al. 1998) is different from that of homocysteine (the glycine-binding site; Lipton et al. 1997). Ethanol is also a well-described effector of neural-tube and neural-crest defects, and fetal alcohol syndrome is widely known among both scientists and laymen. Human use of both ethanol and dextromethorphan is related to cono-truncal defects, according to epidemiological studies in human subjects (for example, see Ferencz et al. 1997). Dextromethorphan blocks the NMDA receptor at the $\mathrm{Ca}$ channel, and it was a potent inducer of neural-crest and neural-tube defects in our experiments with the chicken-embryo model (Andaloro et al. 1998). Another point that added interest to the use of ethanol and dextromethorphan is that they may be the NMDA-receptor antagonists that are most likely to be used by the average individual. When they were given in combination with homocysteine, dextromethorphan as well as ethanol acted synergistically to increase the number of neural-crest and neural-tube defects to a level that was significantly higher than could be predicted from the behaviour of the compounds when any one compound was given independently of the others $(P<0 \cdot 001$, dependent $t$ test to compare the predicted value with the actual value; Rosenquist \& Monaghan, 2000). Furthermore, cross-validation testing showed a correlation coefficient of $<0.50$ between the predicted value and the actual value in all cases, confirming that a prediction of a simple additive effect was incorrect for homocysteine interacting with either ethanol or dextromethorphan.

For the present report we tested this hypothesis further by giving homocysteine to embryos, according to our published method (Rosenquist et al. 1999; Rosenquist \& Monaghan, 2000), in combination with the NMDA-receptor antagonist MK801. MK801 is a well-characterized highly-specific blocker of the NMDA-receptor Ca channel. At a concentration that had been shown to induce no gross developmental abnormalities (Andaloro et al. 1998) MK801 acted synergistically with homocysteine to increase significantly $(P<0.001)$ the rate of abnormal development (Table 2). The greatest effect was for cranio-facial defects, where the number was approximately double that with homocysteine alone. Cysteine given at the same concentration as homocysteine did not induce any detectible signs of abnormal development.

These results predict that the combined effects of two or more NMDA antagonists may be teratogenic, even when the concentration of each substance is in a 'safe' range, giving potential significance to the present study. Homocysteine may have a central role in determining the effect of exogenous NMDA receptor antagonists such as ethanol or dextromethorphan. Homocysteine is one of only two common endogenous substances that are known to be able to inhibit the function of the NMDA receptor, the other substance being kynurenic acid. Of these two substances, only homocysteine is present constantly in the serum, and in concentrations that are relevant to the present hypothesis (Brown et al. 1998).

Thus, it may be predicted that homocysteine always interacts with exogenous compounds in some way, and according to the present results this interaction may be dangerous to the embryo.

By applying pharmacology in conjunction with developmental biology, the results described earlier have provided evidence that the ability to induce abnormal development of the neural crest and neural tube is a common property of NMDA-receptor antagonists, including homocysteine; also, embryos may be rescued from these abnormalities by NMDA-receptor agonists. These data provide support for a role for the NMDA receptor in early neural-crest and neuraltube development. However, these studies were initiated on the basis of pharmacological results; at the time there was no report that any component of the heterodimeric NMDA receptor had been located in the neural crest or neural tube of the early embryo. Recently, we examined both avian and murine embryos during neurulation using antibodies against the NR1 component of the NMDA receptor, and we found that it is expressed in the neural crest and neural tube of both species, during the neural-groove and early neural-tube phases of development (Thomas et al. 2000). The signal was especially strong in the murine neural crest. 
Table 2. Synergistic effect of homocysteine and MK801 in chick embryos treated during the process of neural-tube closure with sufficient homocysteine to induce neural-crest and neural-tube defects in about $30 \%$ of survivors, with the N-methyl-D-aspartate calcium channel blocker MK801 at a dose level that did not induce any defects, or with homocysteine in combination with MK801

\begin{tabular}{|c|c|c|c|c|}
\hline & $\begin{array}{c}\text { Cysteine } \\
(10 \mu \mathrm{mol} / \mathrm{embryo})\end{array}$ & $\begin{array}{c}\text { Homocysteine } \\
(10 \mu \mathrm{mol} / \mathrm{embryo})\end{array}$ & $\begin{array}{c}\text { MK801 } \\
(50 \mu \mathrm{mol} / \mathrm{embryo})\end{array}$ & $\begin{array}{l}\text { Homocysteine } \\
\text { and MK801 }\end{array}$ \\
\hline Normal embryos (\% total; $n$ 280) & 100 & 70 & 100 & $54^{\star \star \star}$ \\
\hline Cranio-facial defects & 0 & 9 & 0 & $19^{\star \star \star}$ \\
\hline Spinal defects & 0 & 28 & 0 & $37^{\star \star *}$ \\
\hline Multiple defects & 0 & 47 & 0 & $55^{\star \star \star}$ \\
\hline
\end{tabular}

Means for abnormal embryos per group were significantly higher than those for homocysteine alone: ${ }^{\star \star \star} P<0 \cdot 001$.

\section{Conclusion}

The information described here supports the hypothesis that homocysteine is a risk factor for neural-crest and neural-tube defects, independent of the ambient folate concentration. The mechanism for this effect appears to be related to the ability of homocysteine to act as an inhibitor of the NMDA receptor.

\section{Summary and conclusions: genes that have a plausible role in the folate-homocysteine story}

The experiments described earlier provide evidence in support of two different hypotheses, each of which describes a possible mechanism for the protective effect of periconceptional folate supplementation. On the one hand, abnormal development of the neural tube and neural crest is a consequence of the inability of the cells in these regions to bind and transport folic acid, because of a defect in a key gene that facilitates these processes. In this case, supplementary folate results in a simple concentration-based stoichiometric response that increases intracellular folate to rescue the embryo.

On the other hand, abnormal development of the neural tube and neural crest is a consequence of elevated homocysteine. At least part of the teratogenic role of hyperhomocysteinaemia appears to be related to its ability to act as an antagonist of the NMDA receptor in the early embryonic neural ectoderm. In this case supplementary folate also has a simple role, acting in the methionine metabolism cycle to reduce homocysteine and thereby to rescue the embryo.

Tests of each of the hypotheses have yielded positive results, and therefore each hypothesis appears to be biologically plausible. As a result, it seems likely that both impaired embryonic folate transport and hyperhomocysteinaemia may contribute to abnormal development of human fetuses, each as an independent risk factor. However, it seems likely as well that these two processes may be able to interact in some way that is not yet known. Currently, we are designing experiments that will test their separate and joint effects on downstream gene expression.

Based on the results described here, there appear to be three general families of genes whose level of expression may need to be considered in the context of these two related hypotheses, under the general topic of gene-nutrient interactions: folate-receptor genes; genes that regulate methionine-homocysteine metabolism; NMDA-receptor genes.

\section{Folate-receptor genes}

Initially, we showed that there was significant strain variability among mice in their relative expressions of folate receptors (Finnell et al. 1997). The results of our experiments with transgenic mice, in which the Folbp 1deficient embryos were grossly abnormal, suggested that Folbp1 may have a critical role in folate homeostasis during development. Furthermore, they suggested that the functional defects in the human homologue of Folbpl (FOLR1) could contribute to similar defects in human subjects. However, a human population-based study failed to show any sign of genetic variation within the coding region of the human homologue FR $\alpha$, and no relationship could be found, therefore, between the expression of this gene and developmental abnormalities in man (Barber et al. 1998, 2000). Indeed, there is the possibility that as yet unknown changes in the $3^{\prime}$ untranslated region of the hFR $\alpha$ gene may explain the population burden of neural-crestrelated birth defects. It is possible as well that the folatetransporter gene (RFC1) is also involved in determining susceptibility to environmentally-induced birth defects. A 'knockout' mouse model of the RFC1 gene is currently being developed and evaluated in our laboratories. It is conceivable that these two genes work together to determine the effectiveness of folate transport in the developing embryo.

\section{Genes that affect homocysteine concentration}

Human population-based studies have shown that mutations in at least three genes that are key for methionine metabolism can result in hyperhomocysteinaemia: MS, CBS, and MThFR. Since maternal hyperhomocysteinaemia per se appears to be a risk factor for neural-tube defects, it was a logical next step to investigate the relationship between neural-crest and neural-tube defects and polymorphisms of MS, CBS and MThFR. Subsequent epidemiological studies have shown at least some evidence that implicates polymorphisms of all three genes in abnormal development.

Mutant forms of the MThFR gene may code for proteins that do not function properly in methionine metabolism, and the resulting elevation in homocysteine is associated in some studies with an increased incidence of abnormal development (Finnell et al. 1997; Shaw et al. 1998, 1999). A thermolabile form of MThFR that results from a common 677 cytosine $\rightarrow$ thymine mutation has a well-known association with the occurrence of neural-tube defects (for 
example, see Harmon et al. 1996; Morrison et al. 1998; Ou et al. 1996; for review, see Botto \& Yang, 2000). As might be expected, this association does not necessarily hold for all ethnic groups (Speer et al. 1997). There is also evidence that the same mutation may be associated with cleft palate (Mills et al. 1999) and heart defects (Eskes, 1998), although this evidence is more equivocal (for example, see Shaw et al. 1999).

With respect to MS, van der Put et al. (1997) reported that there was no significant evidence that it was involved in homocysteine-related diseases such as neural-tube defects. Subsequent findings by other laboratories have also shown a lack of association between MS and abnormal development (for example, see Brody et al. 1999; Christensen et al. 1999). Steen et al. (1998) reported a general association between neural-tube defects and impaired function of MS, while Wilson et al. (1999) found an interesting relationship between low vitamin $\mathrm{B}_{12}$, spina bifida, and a common variant in the enzyme MS reductase, which activates MS.

The CBS story, like that of MThFR and MS, is also mixed. One CBS polymorphism has been associated with the occurrence of lumbo-sacral myelomeningocoele (Speer et al. 1999), whereas other investigators have found no apparent association between abnormal development and CBS (for example, see Ramsbottom et al. 1997; Botto \& Mastroiacovo, 1998).

\section{NMDA-receptor genes}

Many questions remain to be explored. However, the data obtained to date support the hypothesis that the ability to induce neural-tube and neural-crest defects is a general property of NMDA-receptor antagonists. The NMDA receptor is a heterodimer consisting of NR1, NR2 and NR3 subunits (Monaghan et al. 1998). There are seven different genes expressing NR1 subunits (NR1a-g) and four different genes for the NR2 subunit (NR2A-D), and there is a welldescribed heterogeneity in the anatomical distribution of the various combinations of subunits that make up the NMDAreceptor subtypes (for example, see Wenzel et al. 1997; Winkler et al. 1999). This complex subunit diversity is also related to function, where different subunit combinations show different responses (Monaghan et al. 1998). Although we have shown that the NMDA receptor is present in the neural-crest cells of the early embryo, we do not yet have any data regarding the kind of subunits that may be present. Indeed, there, are no published data on the type of NMDA receptors that may be present in the early embryo of any species, or their distribution. Thus, our first task will be to complete these types of analyses; a complex task, given the heterogeneous nature of the receptor. With these data, it may be possible to investigate an association between NMDAreceptor polymorphisms and abnormal development.

Currently, there are no reports of naturally-occurring mutations of the NMDA receptor. Induced mutations in transgenic mice have shown quite clearly that polymorphisms in the NMDA receptor are associated with altered function (for example, see Wood et al. 1999; Single et al. 2000); one mutation to the glycine site reduced the affinity of glycine for the NMDA receptor by 40-50-fold
(Wafford et al. 1995). Thus, it may be predicted that the homocysteine-NMDA receptor interaction will be altered by those polymorphisms that are discovered ultimately.

\section{Acknowledgements}

This work was supported by United States Public Health Services National Institutes of Health grants RO1-DE13613, RO1-JD-35396 (R.F.); and RO1-HL-55940, RO1HL-58969 (T.R.).

\section{References}

Andaloro VJ, Monaghan DT \& Rosenquist TH (1998) Dextromethorphan and other N-methyl D-asparate receptor antagonists are teratogenic in the avian embryo model. Pediatrics Research 43, 1-7.

Barber RC, Shaw GM, Lammer EJ, Greer KA, Lacey SW, Wasserman CR \& Finnell RH (1998) Lack of association between mutations in the folate receptor alpha gene and spina bifida. American Journal of Medical Genetics 76, 310-317.

Barber RC, van Waes JG, Lammer EJ, Shaw GM, Rosenquist TH \& Finnell RH (2000) Folic acid and homocysteine and risk factors for neural tube defects. In Folate and Human Development [EJ Massaro, editor]. Totowa, NJ: Humana Press (In the Press).

Bhave SV, Snell LD, Tabakoff B \& Hoffman PL (1996) Mechanism of ethanol inhibition of NMDA receptor function in primary cultures of cerebral cortical cells. Alcoholism, Clinical and Experimental Research 20, 934-941.

Bockman DE, Redmond ME \& Kirby ML (1990) Altered development of pharyngeal arch vessels after neural crest ablation. Annals of the New York Academy of Sciences $\mathbf{5 8 8}$, 296-304

Botto LD, Khoury MJ, Mulinare J \& Erickson JD (1996) Periconceptional multivitamin use and the occurrence of conotruncal heart defects: results from a population-based, case-control study. Pediatrics 98, 911-917.

Botto LD \& Mastroiacovo P (1998) Exploring gene-gene interactions in the etiology of neural tube defects. Clinical Genetics 53, 456-459.

Botto LD \& Yang Q (2000) 5,10-Methylenetetrahydrofolate reductase gene variants and congenital anomalies: a HuGE review. American Journal of Epidemiology 151, 862-877.

Brody LC, Baker PJ, Chines PS, Musick A, Molloy AM, Swanson DA, Kirke PN, Ghosh S, Scott M \& Mills JL (1999) Methionine synthase: high-resolution mapping of the human gene and evaluation as a candidate locus for neural tube defects. Molecular Genetics Metabolism 67, 324-333.

Brown JC, Rosenquist TH, \& Monaghan DT (1998) ERK2 activation by homocysteine in vascular smooth muscle cells. Biochemical and Biophysical Research Communications 251, 669-676.

Christensen B, Arbour L, Tran P, Leclerc D, Sabbaghian N, Platt R, Gilfix BM, Rosenblatt DS, Gravel RA, Forbes P \& Rozen R (1999) Genetic polymorphisms in methylenetetrahydrofolate reductase and methionine synthase, folate levels in red blood cells, and risk of neural tube defects. American Journal of Medical Genetics 84, 151-157.

Cornell-Bell AH, Thomas PG \& Smith SJ (1990) The excitatory neurotransmitter glutamate causes filopodia formation in cultured hippocampal astrocytes. Glia 3, 322-324.

Czeizel A \& Rode K (1984) Trial to prevent first occurrence of neural tube defects by periconceptional multivitamin supplementation (letter). Lancet ii, 40. 
Czeizel AE, Toth M \& Rockenbauer M (1996) Population-based case control study of folic acid supplementation during pregnancy. Teratology 53, 345-351.

Eskes TK (1998) Open or closed? A world of difference: a history of homocysteine research. Nutrition Reviews 56, 236-244.

Ferencz C, Loffredo CA, Correa Villaseñor \& Wilson PD (editors) (1997) Perspectives in Pediatric Cardiology, vol.5: Genetic and Environmental Risk Factors of Major Cardiac Malformations. The Baltimore-Washington Infant Study, 1981-1989. Armonk, NY: Futura Publishing Co. Inc.

Finnell RH, Shaw GM, Greer KA, Barber RC \& Lammer EJ (1998) Folate receptors and neural tube defects with special emphasis on craniofacial development. Critical Reviews in Oral Biology and Medicine 9, 38-53.

Finnell RH, Wlordarczyk BC, Craig JC, Piedrahita JA \& Bennett GD (1997) Strain dependent alterations in the expression of folate pathway genes following teratogenic exposure to valproic acid in a mouse model. American Journal of Medical Genetics 70, 303-311.

Gofflot F, van Maele Fabry G \& Picard JJ (1996) Cranial nerves and ganglia are altered after in vitro treatment of mouse embryos with valproic acid (VPA) and 4-en-VPA. Developmental Brain Research 93, 62-69.

Graham A, Koentges G \& Lumsden A (1996) Neural crest apoptosis and the establishment of craniofacial pattern: an honorable death. Molecular and Cellular Neuroscience 8, 76-83.

Graham A \& Lumsden A (1996) Patterning the neural crest. Biochemical Society Symposia 62, 77-83.

Harmon DL, Woodside JV, Yarnell JW, McMaster D, Young IS, McCrum EE, Gey KF, Whitehead AS \& Evans AE (1996) The common 'thermolabile' variant of methylene tetrahydrofolate reductase is a major determinant of mild hyperhomocysteinaemia. Quarterly Journal of Medicine 89, 571-577.

Hundt W, Danysz W, Holter SM \& Spanagel R (1998) Ethanol and $\mathrm{N}$-methyl-D-aspartate receptor complex interactions: a detailed drug discrimination study in the rat. Psychopharmacology (Berlin) 135, 44-51.

Johnson VP, Swayze VW II, Sato Y \& Andreasen NC (1996) Fetal alcohol syndrome: craniofacial and central nervous system manifestations. American Journal of Medical Genetics 61, 329-339.

Kapusta L, Haagmans ML, Steegers EA, Cuypers MH, Blom HJ \& Eskes TK (1999) Congenital heart defects and maternal derangement of homocysteine metabolism. Journal of Pediatrics 135, 773-774.

Kirby ML, Gale TF \& Stewart DE (1983) Neural crest cells contribute to normal aorticopulmonary septation. Science $\mathbf{2 2 0}$, 1059-1061.

Kirby ML \& Waldo KL (1990) Role of neural crest in congenital heart disease. Circulation 82, 332-340.

Kirby ML \& Waldo KL (1995) Neural crest and cardiovascular patterning. Circulation Research 77, 211-215.

Komuro H \& Rakic P (1993) Modulation of neuronal migration by NMDA receptors. Science 260, 95-97.

Lipton SA, Kim WK, Choi YB, Kumar S, D’Emilia DM, Rayudu PV, Arnelle DR \& Stamler JS (1997) Neurotoxicity associated with dual actions of homocysteine at the N-methyl-D-aspartate receptor. Proceedings of the National Academy of Sciences USA 94, 5923-5928.

Mills JL, Kirke PN, Molloy AM, Burke H, Conley MR, Lee YJ, Mayne PD, Weir DG \& Scott JM (1999) Methylenetetrahydrofolate reductase thermolabile variant and oral clefts. American Journal of Medical Genetics 86, 71-74.

Monaghan DT, Andaloro VJ \& Skifter DA (1998) Molecular determinants of NMDA receptor pharmacological diversity. Progress in Brain Research 116, 171-190.
Morrison K, Papapetrou C, Hol FA, Mariman EC, Lynch SA, Burn J \& Edwards YH (1998) Susceptibility to spina bifida; an association study of five candidate genes. Annals of Human Genetics 62, 379-396.

Munger RG, Romitti PA, Daack Hirsch S, Burns TL, Murray JC \& Hanson J (1996) Maternal alcohol use and risk of orofacial cleft birth defects. Teratology 54, 27-33.

Nau H (1985) Teratogenic valproic acid concentrations: infusion by implanted minipumps vs conventional injection regimen in the mouse. Toxicology and Applied Pharmacology 80, 243-250.

Noden DM (1975) An analysis of migratory behavior of avian cephalic neural crest cells. Developmental Biology 42, 106-130.

Noden DM (1978a) The control of avian cephalic neural crest cytodifferentiation. I. Skeletal and connective tissues. Developmental Biology 67, 296-312.

Noden DM (1978b) The control of avian cephalic neural crest cytodifferentiation. II. Neural tissues. Developmental Biology 67, 313-329.

Noden DM (1983) The embryonic origins of avian cephalic and cervical muscles and associated connective tissues. American Journal of Anatomy 68, 257-276.

Ou CY, Stevenson RE, Brown VK, Schwartz CE, Allen WP, Khoury MJ, Rozen R, Oakley GP Jr \& Adams MJ Jr (1996) 5,10 Methylenetetrahydrofolate reductase genetic polymorphism as a risk factor for neural tube defects. American Journal of Medical Genetics 63, 610-614.

Piedrahita JA, Oetama B, Bennett GD, van Waes J, Lacey SW, Kamen BA, Richardson JA, Anderson RG \& Finnell RH (1999) Mice lacking the folic acid-binding protein are defective in early embryonic development. Nature Genetics 23, 228-232.

Ramsbottom D, Scott JM, Molloy A, Weir DG, Kirke PN, Mills JL, Gallagher PM \& Whitehead AS (1997) Are common mutations of cystathionine beta-synthase involved in the aetiology of neural tube defects? Clinical Genetics 51, 39-42.

Rashid NA \& Cambray-Deakin MA (1992) N-methyl-D-aspartate effects on the growth, morphology and cytoskeleton of individual neurons in vitro. Brain Research 67, 301-308.

Rosenquist TH \& Beall AC (1990a) Elastogenic cells in the developing cardiovascular system: smooth muscle, non-muscle and cardiac neural crest. Annals of the New York Academy of Sciences 588, 106-119.

Rosenquist TH, Beall AC, Modis L \& Fishman R (1990b) Impaired elastic matrix development in the great arteries after ablation of the cardiac neural crest. Anatomical Record 226, 347-359.

Rosenquist TH, Fray-Gavalas CA, Waldo K \& Beall AC (1990c) Development of the musculoelastic septation complex in the avian truncus arteriosus. American Journal of Anatomy 180, 339-459.

Rosenquist TH, McCoy JR, Waldo K \& Kirby ML (1988) Origin and propagation of elastogenesis in the cardiovascular system. Anatomical Record 221, 860-871.

Rosenquist TH \& Monaghan DT (2000) Homocysteine and the NMDA receptor: Are they keys to conotruncal abnormalities? In Cardiovascular Development [R Tomanek and R Runyan, editors]. (In the Press).

Rosenquist TH, Ratashak SA \& Selhub J (1996) Homocysteine induces congenital heart and neural tube defects. Effect of folic acid. Proceedings of the National Academy of Sciences USA $\mathbf{9 3}$, 15227-15232.

Rosenquist TH, Schneider A \& Monaghan DT (1999) NMDA receptor agonists modulate homocysteine-induced developmental abnormalities. FASEB Journal 13, 1523-1531.

Scherson T, Serbedzija G, Fraser S \& Bronner-Fraser M (1993) Regulative capacity of the cranial neural tube to form neural crest. Development 118, 1049-1062.

Seller MJ \& Nevin NC (1984) Periconceptional vitamin supplementation and the prevention of neural tube defects in South-East 
England and Northern Ireland. Journal of Medical Genetics 21, 325-330.

Shaw GM, O'Malley CD, Wasserman CR, Tolarova MM \& Lammer EJ (1995) Maternal periconceptional use of multivitamins and reduced risk for conotruncal heart defects and limb deficiencies among offspring. American Journal of Medical Genetics 59, 536-545.

Shaw GM, Rozen R, Finnell RH, Todoroff K \& Lammer EJ (1998) Infant C677T mutation in MTHFR, maternal periconceptional vitamin use, and cleft lip. American Journal of Medical Genetics 80, 196-198.

Shaw GM, Todoroff K, Finnell RH, Rozen R \& Lammer EJ (1999) Maternal vitamin use, infant C677T mutation in MTHFR, and isolated cleft palate risk (letter). American Journal of Medical Genetics 85, 84-85.

Single FN, Rozov A, Burnashev N, Zimmermann F, Hanley DF, Forrest D, Curran T, Jensen V, Hvalby O, Sprengel R \& Seeburg PH (2000) Dysfunctions in mice by NMDA receptor point mutations NR1(N598Q) and NR1(N598R). Journal of Neuroscience 20, 2558-2566.

Speer MC, Nye J, McLone D, Worley G, Melvin EC, Viles KD, Franklin A, Drake C Mackey J \& George TM (1999) Possible interaction of genotypes at cystathionine beta-synthase and methylenetetrahydrofolate reductase (MTHFR) in neural tube defects. NTD Collaborative Group. Clinical Genetics 56, $142-144$.

Speer MC, Worley G, Mackey JF, Melvin E, Oakes WJ \& George TM (1997) The NTD Collaborative Group. The thermolabile variant of methylenetetrahydrofolate reductase (MTHFR) is not a major risk factor for neural tube defect in American Caucasians. Neurogenetics 1, 149-150.

Steegers-Theunissen RP, Boers GH, Blom HJ, Nijhuis JG, Thomas CM, Borm GF \& Eskes TK (1995) Neural tube defects and elevated homocysteine levels in amniotic fluid. American Journal of Obstetrics and Gynecology 172, 1436-1441.

Steegers-Theunissen RP, Boers GH, Trijbels FJ, Finkelstein JD, Blom HJ, Thomas CM, Borm GF, Wouters MG \& Eskes TK (1994) Maternal hyperhomocysteinemia: a risk factor for neural-tube defects? Metabolism: Clinical and Experimental 43, $1475-1480$

Steen MT, Boddie AM, Fisher AJ, Macmahon W, Saxe D, Sullivan KM, Dembure PP \& Elsas LJ (1998) Neural-tube defects are associated with low concentrations of cobalamin (vitamin B12) in amniotic fluid. Prenatal Diagnosis 18, 545-555.

Thieszen SL, Dalton M, Gadson PF, Patterson E \& Rosenquist TH (1996) Embryonic lineage of vascular smooth muscle cells determines responses to collagen matrices and integrin receptor expression. Experimental Cell Research 227, 135-145.

Thieszen SL \& Rosenquist TH (1995) Developmental regulation of decorin and collagen: implications for matrix pattern formation. Matrix Biology 14, 573-582.

Thomas CM, Borm GF, Wouters MG \& Eskes TK (1994) Maternal hyperhomocysteinemia: a risk factor for neural-tube defects? Metabolism: Clinical and Experimental 43, 1475-1480.
Thomas MP, Rosenquist TH \& Monaghan DT (2000) Evidence for early developmental expression of NMDA receptors in chick embryos. FASEB Journal 14, A545.

Uberti D, Belloni M, Grilli M, Spano P \& Memo M (1998) Induction of tumour-suppressor phosphoprotein p53 in the apoptosis of cultured rat cerebellar neurones triggered by excitatory amino acids. European Journal of Neuroscience $\mathbf{1 0}$, 246-254.

van der Put NM, Steegers-Theunissen RP, Frosst P, Trijbels FJ, Eskes TK, van den Heuvel LP, Mariman EC, den Heyer M, Rozen R \& Blom HJ (1995) Mutated methylenetetrahydrofolate reductase as a risk factor for spina bifida. Lancet $\mathbf{3 4 6}$, 1070-1071.

van der Put NM, Thomas CM, Eskes TK, Trijbels FJ, SteegersTheunissen RP, Mariman EC, de Graaf Hess A, Smeitink JA \& Blom HJ (1997) Altered folate and vitamin B12 metabolism in families with spina bifida offspring. Quarterly Journal of Medicine 90, 505-510.

Wafford KA, Kathoria M, Bain CJ, Marshall G, Le-Bourdelles B, Kemp JA \& Whiting PJ (1995) Identification of amino acids in the N-methyl-D-aspartate receptor NR1 subunit that contribute to the glycine binding site. Molecular Pharmacology 47, 374-380.

Wald NJ, Hackshaw AD, Stone R \& Sourial NA (1996) Blood folic acid and vitamin $\mathrm{B}_{12}$ in relation to neural tube defects. British Journal of Obstetric Gynecology 103, 319-324.

Wang C, Pralong WF, Schulz MF, Rougon G, Aubry JM, Pagliusi S, Robert A \& Kiss JZ (1996) Functional N-methyl-D-asparate receptors in O-2A glial precursor cells: a critical role in regulating polysialic acid-neural cell adhesion molecule expression and cell migration. Journal of Cell Biology 135, $1565-1581$.

Weil M, Jacobson MD \& Ratt MC (1997) Is programmed cell death required for neural tube closure? Current Biology 7, 281-284.

Wenzel A, Fritschy JM, Mohler H \& Benke D (1997) NMDA receptor heterogeneity during postnatal development of the rat brain: differential expression of the NR2A, NR2B, and NR2C subunit proteins. Journal of Neurochemistry 68, 469-478.

Wilson A, Platt R, Wu Q, Leclerc D, Christensen B, Yang H, Gravel RA \& Rozen RA (1999) Common variant in methionine synthase reductase combined with low cobalamin (vitamin B12) increases risk for spina bifida. Molecular Genetics Metabolism 67, 317-323.

Winkler A, Mahal B, Kiianmaa K, Zieglgansberger W \& Spanagel $R$ (1999) Effects of chronic alcohol consumption on the expression of different NR1 splice variants in the brain of AA and ANA lines of rats. Brain Research 72, 166-175.

Wood MW, VanDongen HM \& VanDongen AM (1999) A mutation in the glycine binding pocket of the N-methyl-Daspartate receptor NR1 subunit alters agonist efficacy. Brain Research 73, 189-192.

Yates JRW, Ferguson Smith MA, Shenkin A, Guzman-Rodriguez R, White M \& Clark BJ (1987) Is disordered folate metabolism the basis of the genetic predisposition to neural tube defects. Clinical Genetics 31, 219-238. 